\title{
Hydrological properties of bark of selected forest tree species. Part I: the coefficient of development of the interception surface of bark
}

\author{
Ilek Anna $\cdot$ Kucza Jarosław
}

Received: 8 August 2013/Revised: 3 February 2014/ Accepted: 12 February 2014/Published online: 5 March 2014 (C) The Author(s) 2014. This article is published with open access at Springerlink.com

\begin{abstract}
Key message The coefficient of development of the interception surface of bark allows for objective assessment of the degree of bark surface differentiation between different species.

Abstract Inter-species differentiation of bark morphology and its variability progressing with tree age suggest that the hydrological properties of the bark of particular species depend on the degree of development of the outer bark surface of trees. The aim of the present research was to develop a method of calculating the actual bark surface with the use of the coefficient of development of the interception surface of bark, describing the degree of development of the outer bark surface of trees. The primary aim was to show inter-species differentiation of the coefficient of development of the interception surface of bark at breast height, as well as its variability within a single species, progressing with tree age. The present study shows the results obtained for 77 bark samples collected at the breast height of the following tree species: Pinus sylvestris L., Larix decidua Mill., Abies alba Mill., Picea abies L., Quercus robur L., Fagus sylvatica L., Acer pseudoplatanus L. and Betula pendula Ehrh. In all of the examined species, the coefficient of development of the interception surface of bark shows a distinct relation to the breast-height
\end{abstract}

Communicated by H. Pfanz.

I. Anna $(\bowtie) \cdot$ K. Jarosław

Department of Forest Engineering, Faculty of Forestry,

University of Agriculture in Cracow, Al. 29 Listopada 46,

31425 Cracow, Poland

e-mail: a.ilek@wp.pl

K. Jarosław

e-mail: j.kucza@ur.krakow.pl diameter. The highest values of coefficient of development of the interception surface of bark among the thickest trees are reached by: L. decidua-2.56, Pinus sylvestris-2.28 and $B$. pendula-2.44, whereas the lowest values are reached by the bark of European beech $F$. sylvatica-1.07. The coefficient of development of the interception surface of bark describes the morphological differentiation of the outer bark surface of trees in an objective way. Owing to its mathematical form, the coefficient of development of the interception surface of bark may be useful in the modelling of hydrological processes occurring in forest ecosystems.

Keywords Forest hydrology · Plant interception - Bark of forest trees - Bark surface - Coefficient of development of the interception surface of bark

\section{Introduction}

The bark of forest trees has a number of various functions. From the point of view of the formation of water balance in forest ecosystems, what is focused on is the role of bark in rainfall retention (Herwitz 1985; Levia and Herwitz 2005; Levia and Wubbena 2006; Valovà and Bieleszovà 2008) as well as the influence of the differences in bark roughness and water capacity in different tree species on the size of stemflow production (Návar 1993; Aboal et al. 1999; Levia et al. 2010; Van Stan and Levia 2010). Bark constitutes the environment for the life of numerous organisms, such as bryophytes and lichens, whose species composition and distribution over the bark surface largely depend on differences in the texture and acidity of the bark of different forest tree species (Bates and Brown 1981; Stephenson 1989; Kuusinen 1996; Everhart et al. 2009; Öztürk and Güvenç 2010; Öztürk and Oran 2011). In the literature, it is 
stated that bark may be used in the biomonitoring of air pollution (Schulz et al. 1999) and that it is important in the protection of the vascular cambium during the occurrence of heat stress caused by forest fires. Among important factors that are frequently decisive in the survival of a tree during a fire are bark thickness (Harmon 1984; Hengst and Dawson 1994; Pinard and Huffman 1997; Barlow et al. 2003) and its volume density (Bauer et al. 2010).

The interception of rainfall by forest trees is a complex process, dependent on many factors, such as rainfall intensity, duration, and raindrop size (Calder 1996, 1999; Suliński et al. 2001). The interception ability is closely connected with the total surface of the overground parts of a plant, which is largely determined by the plant species, its height, weight, and morphological features (Cebulska and Osuch 1998; Keim et al. 2006). Research on plant interception, understood as a process of rainfall detention by the whole surface of a plant (Suliński et al. 2001), do not allow for distinguishing the extent to which the amount of intercepted water is affected by the surface of leaves, branches or the stem. Research focused only on the rainwater interception by leaves may understate the actual water capacity of the tree crowns, and consequently lead to an underestimation of the role of bark in rainwater retention (Klaassen et al. 1998). Given the heterogeneity of the various parts of the plant, its surfaces with different retention properties must be considered separately. Therefore, there is a need to divide the plant into the surface of leaves, shoots and bark, whose water retention properties vary depending on the age (Osuch 1998; Osuch et al. 2005a, b).

The bark of forest trees is a structure which undergoes constant changes due to the dying of some tissues and the growth of new ones (Grochowski 1990). The water capacity of bark depends on the properties of the bark tissue, such as its thickness and texture, which change with the tree age and thickness (Hengst and Dawson 1994; Pinard and Huffman 1997; Pypker et al. 2011). The bark of different species is very diversified with respect to its thickness and texture-from extremely rough to completely smooth (Jackson 1979; West 2009). For example, the surface of bark of Scots pine Pinus sylvestris L. and beech Fagus sylvatica L., of the same thickness and height, will differ due to their different structure. Pine bark has numerous cracks and fissures, while beech bark is relatively smooth over the entire length of the stem. Thus, the active area of the bark taking part in the interception of rainwater will differ greatly between these two species. Differences in the degree of development of the bark surface between these species may suggest that the potential interception capacities of the pine bark surface will be larger than the potential interception capacities of the beech bark surface.
Morphological differentiation of bark occurs also within a single species. For example, Pawłowski (1956) described three types of outer bark of Norway spruce Picea abies L.: numularis with round flakes, squamata with slightly elongated flakes and corticata with quite thick flakes. Similarly, Eremin (1977) classified the three types of outer bark in spruce as four categories by including anatomical characteristics. Etverk (1972) attempted to analyse the succession of features of outer bark in spruce by distinguishing the following forms: rimescocarta, globocarta and an intermediate form. According to research by Hoffmann (1958), the features of bark in Norway spruce are also related to the conditions of tree growth. The richer and more abundant the habitat, the thicker the bark formed by this species.

The differentiation of the bark surface is relatively hard to parametrize and there is little information on the methods of its measurement. An attempt to determine the allometry of bark thickness was made by Harmon (1984) as well as by Adams and Jackson (1995). MacFarlane and Luo (2009) described the bark structure of 15 tree species using the bark-fissure index (BFI) while Van Stan et al. (2010) constructed a device which measures the bark microrelief.

Owing to inter-species differentiation in the bark morphology and its variability progressing with tree age, research on interception and water capacity of bark should take into consideration its actual surface. Therefore, the object of this study is the actual surface of the bark of the stem of selected forest tree species, including its morphological properties. The aim of the study was (1) to develop and propose a method of calculating the actual surface of the bark $A_{\mathrm{d}}$ by means of the coefficient of development of the interception surface $C_{\mathrm{sd}}$. describing the degree of development of the outer bark layer in trees; and (2) to demonstrate the interspecies differences in the shaping of the coefficient of development of the interception surface $C_{\text {sd }}$ at breast height and its variability within a single species, progressing with the age of trees.

The coefficient of development of the interception surface $C_{\text {sd }}$ can be defined as the ratio of the actual surface $A_{\mathrm{d}}$ of a bark sample to the surface of a section of the cylinder corresponding to the smooth surface of the examined sample. Assuming that the surface of the bark of the stem was perfectly smooth, the coefficient of development of the interception surface $C_{\text {sd }}$ would have the minimum value of 1.0. The greater the coefficient of development of the interception surface $C_{\mathrm{sd}}$, the more developed the actual surface of the stem bark $A_{\mathrm{d}}$ and the greater the theoretical possibility of retaining the rainwater which is in direct contact with the bark and which flows down the stem.

The inspiration for the present study was experiments on the water capacity of the bark of different tree species; their results are presented in Part II of this study. 


\section{Materials and methods}

The research area

Bark samples were collected in the Trzebunia Forest Subdistrict $\left(49^{\circ} 46^{\prime} 28^{\prime \prime} \mathrm{N}, 19^{\circ} 51^{\prime} 51^{\prime \prime} \mathrm{E}\right)$, which is part of the Myślenice Forest District, located in the southern Beskid Makowski in central Poland. The samples were obtained from the bark of the trees growing on the mixed mountain forest habitat, on an eastern slope within the altitudes from 650 to $700 \mathrm{~m}$.

The scope of the research

The study included eight species of forest trees: Scots pine (P. sylvestris L.), European larch (Larix decidua Mill.), silver fir (Abies alba Mill.), Norway spruce ( $P$. abies L.), common oak (Quercus robur L.), European beech ( $F$. sylvatica L.), sycamore maple (Acer pseudoplatanus L.), and silver birch (Betula pendula Ehrh.). The bark samples were obtained during the summer of 2011, after the beginning of the growing season of the trees, which made it possible to sample the study material without mechanical damage to bark. The samples were collected using a saw, a knife and a chisel from the stems of living trees at breast height $(1.3 \mathrm{~m})$ by cutting, on the tree side facing the top of the slope, possibly rectangular pieces of bark with the size dependent on the thickness of the tree. Because the bark samples were obtained from trees growing under the same site conditions, the elaboration of the results was based on the assumption that tree thickness is the measure of their age. To demonstrate variation of the bark surface between the different species as well as the coefficient of development of the interception surface $C_{\mathrm{sd}}$ together with age, from 6 to 11 bark samples were collected for each species from trees with thickness ranging from 5 to $60 \mathrm{~cm}$.

The actual bark surface

The actual surface of the bark in each sample was assumed to be the surface with all irregularities, cracks and cavities. According to the present authors, the actual surface can be calculated according to the formula:

$A_{\mathrm{d}}=A \cdot C_{\mathrm{sd}}$

where $A_{\mathrm{d}}$ is the actual surface of the bark sample $\left(\mathrm{cm}^{2}\right)$; $A$ is the model surface of a bark sample $\left(\mathrm{cm}^{2}\right)$, corresponding to the surface of the cylinder slice; $C_{\mathrm{sd}}$ is the coefficient of development of the interception surface, describing the level of development of the outer bark layer of the trees.
Determination of the parameters needed to calculate the actual bark surface $A_{\mathrm{d}}$ required the use of a number of measurement and calculation procedures, details of which are shown below.

The model surface

The model surface for all tested samples of bark was calculated according to the formula:

$A=l_{\mathrm{a}} \cdot b_{\mathrm{a}}$

where $A$ is the model surface $\left(\mathrm{cm}^{2}\right) ; l_{\mathrm{a}}$ is the average length of the side of the bark sample $(\mathrm{cm})$, parallel to the core of a tree stem; $b_{\mathrm{a}}$ is the average value of the sample width (curvature) $(\mathrm{cm})$.

The length of the side parallel to the stem core $l_{\mathrm{a}}$ was calculated from the arithmetic mean of several lengths $l_{i}$ measured with calipers. Measurements of lengths $l_{i}$ were taken at regular intervals $(0.5-1.0 \mathrm{~cm})$, and their number was dependent on the width of the sample.

When calculating the average width (curvature) of the bark samples $b_{\mathrm{a}}$, the researchers had to apply the geometrical relationships related to the circle. For this purpose, it was assumed that the cross section of the examined tree stems was round. This assumption allowed the calculation of the average radius of the tree cross section $R$, based on standard measurements of the tree diameter at breast height $(\mathrm{DBH})$, carried out in two directions perpendicular to each other. The study sought to choose the trees in which the values of the two diameters did not differ from each other by more than $2 \mathrm{~cm}$.

To calculate the length of the curvature $b_{\mathrm{a}}$, individual bark samples were cut with a $0.6 \mathrm{~mm}$ thick saw into stripes with the width $s$, dependent on the length of the sample (Fig. 1). For each bark sample, the constant width $s$ was adopted, located in the range from 0.5 to $1.0 \mathrm{~cm}$. The division of the bark samples into strips was performed after the completion of a series of experiments of simulated rainfall, when the samples were in a state of maximum filling with water.

The cross sections of the strips of each bark sample were scanned at a scale of $1: 1$, in the resolution between 600 and 1,200 dpi. The choice of image resolution was dependent on the degree of differentiation of the surface of the bark. It should be noted that although the cross sectional line is dimensionless, after cutting the bark with a saw with $0.6 \mathrm{~mm}$ thickness, the two sides of the cross section were different from each other. Therefore, the surfaces of the cross sections were scanned in two versions: first all of the upper sections and then all bottom sections of the strips which made up the sample (Fig. 1). Before scanning the cross sections, it was necessary to check whether the 


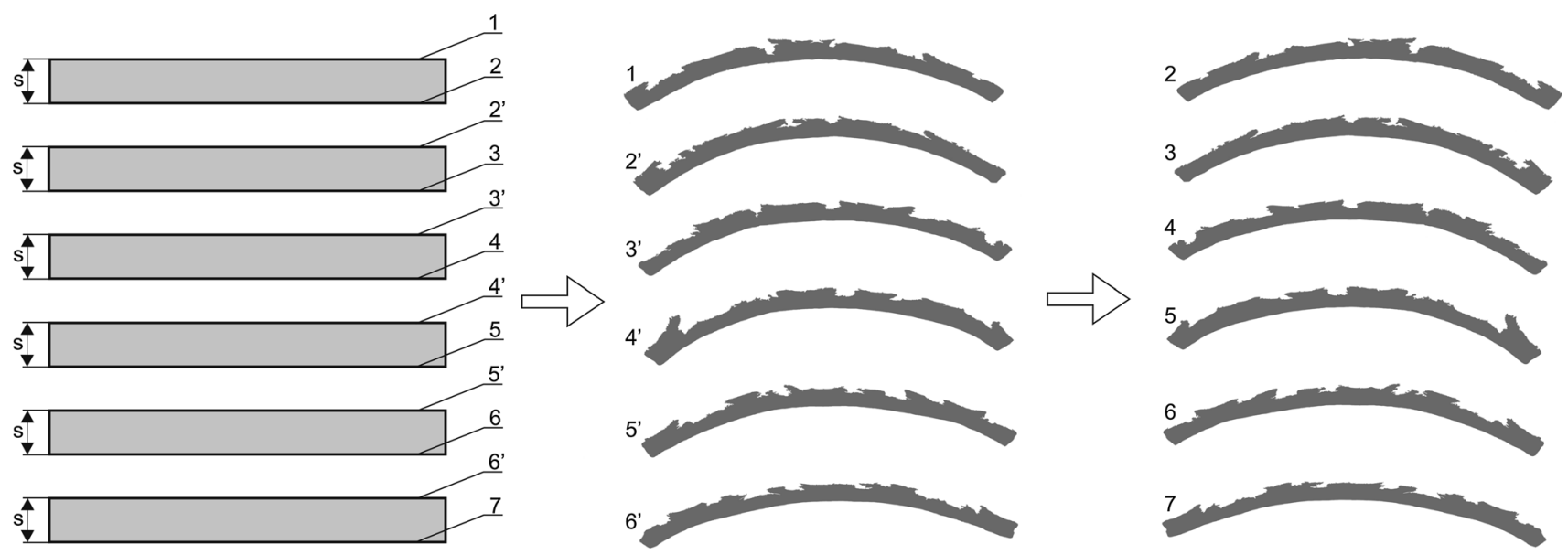

Fig. 1 An example of the division of a bark sample into strips with corresponding cross sections, where $s$ is the strip width in the range from 0.5 to $1.0 \mathrm{~cm} ; 1,2^{\prime}-6^{\prime}$ are the upper cross sectional scans of each strip; $2-7$ are lower cross sectional scans of the strips

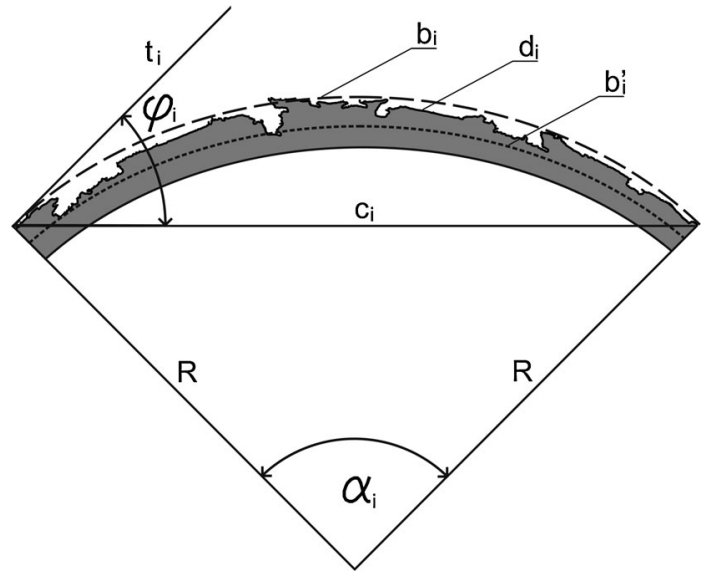

Fig. 2 A diagram showing the parameters measured and calculated for each cross section of a bark strip, where $R$ is the radius of the tree, $c_{i}$ is the chord of a section of a bark arc, $t_{i}$ is the tangent passing through the extreme point of the arc, $\varphi_{i}$ is a girth angle, $\alpha_{i}$ is the central angle of a bark section, $d_{i}$ is the length of the cross sectional contour line, $b_{i}$ is the length of the arc cross section, calculated according to geometrical relations, $b_{i}^{\prime}$ is the length of the curvature of the cross section, calculated in a subjective manner

curvature of the individual strips of bark corresponded to the radius $R$ of the tree from which it was collected. This was done by means of previously prepared templates. In the event, when non-compliance with the radius of the tree was noted, the templates allow for giving the strips the shape of the original curvature.

Measurements of all parameters needed for further calculations were made in the SigmaScan Pro.5 software on the basis of scanned images.

To calculate the curvature $b_{\mathrm{a}}$ of a given bark sample, for each cross section the bark section chord $c_{i}$ was measured (Fig. 2), which, together with the radius of the tree $R$, was used to calculate the length of the curve $b_{i}$ of particular cross sections. Using the formula for the chord length $c_{i}$, which is

$c_{i}=2 \cdot R \cdot \sin \varphi i$

the value of the girth angle $\varphi_{i}\left(^{\circ}\right)$ was calculated between the chord $c_{i}$, and the tangent $t_{i}$ passing through the extreme point of the arc on the surface of the bark (Fig. 2). On the basis of the girth angle $\varphi_{i}$, for each cross section, the central angle $\alpha_{i}\left({ }^{\circ}\right)$ of the arc segment was calculated using the formula:

$\alpha_{i}=2 \cdot \varphi_{i}$

Knowledge of the central angle $\alpha_{i}$ of a section of the circle allowed for the calculation of the length of the $\operatorname{arc} b_{i}$ $(\mathrm{cm})$ of individual strips of bark, using the formula:

$b_{i}=\left(\alpha_{i} / 180^{\circ}\right) \cdot \pi \cdot R$

On the basis of the calculated values $b_{i}$ of individual sections, the length of the curvature of a sample $b_{\mathrm{a}}$ was calculated as the arithmetic mean of all values $b_{i}$.

The presented procedure for calculating the length of the average curvature $b_{\mathrm{a}}$ of particular bark samples was aimed to create a uniform and objective basis for these calculations for all examined samples. Figure 2 shows another way of determining the average length of the curvature of a bark sample $b_{\mathrm{a}}^{\prime}$. The method consisted in measuring the length of curves $b_{i}^{\prime}$ for individual strips as a line following, in a subjective manner, possibly the deepest depressions in the cross section of a given strip. The average length of curvature of a bark sample $b_{\mathrm{a}}^{\prime}$ was calculated as the arithmetic mean of the value $b_{i}^{\prime}$ calculated for all cross sections of a given bark sample. When using this method, formula 2 for the model surface takes the form: 
$A^{\prime}=l_{\mathrm{a}} \cdot b_{\mathrm{a}}^{\prime}$

where $A^{\prime}$ is the model surface of a sample $\left(\mathrm{cm}^{2}\right) ; l_{\mathrm{a}}$ is the average length of a side of a bark sample, parallel to the core of the tree stem $(\mathrm{cm}) ; b_{\mathrm{a}}^{\prime}$ is the average width of a sample, calculated with the subjective method $(\mathrm{cm})$. Analogously, formula 1 for the calculation of the actual surface, described in the previous section, takes the form:

$A_{\mathrm{d}}^{\prime}=A^{\prime} \cdot C_{\mathrm{sd}}^{\prime}$

where $A_{\mathrm{d}}^{\prime}$ is the actual surface of a bark sample $\left(\mathrm{cm}^{2}\right) ; A^{\prime}$ is the model surface defined by formula $6\left(\mathrm{~cm}^{2}\right) ; C_{\mathrm{sd}}^{\prime}$ is the coefficient of development of the interception surface of bark, calculated as described further below.

The coefficient of development of the interception surface

The next stage, leading to the determination of the coefficient of development of the interception surface $C_{\mathrm{sd}}$ and $C_{\mathrm{sd}}^{\prime}$, consists in measuring the length of the contour lines $d_{i}$ of particular cross sections of a given bark sample (Fig. 2). The length of the contour line $d_{i}$ allows for the calculation of the degree of its distortion with respect to the length of the curvature $b_{i}$ or $b_{i}^{\prime}$ of a given cross section. As a measure of this irregularity, one can regard the coefficient of development of the contour line of the cross section $C_{s k i}$ or $C_{s k i}^{\prime}$, calculated according to the formulas:

$C_{s k i}=\frac{d_{i}}{b_{i}}$

or

$C_{s k i}^{\prime}=\frac{d_{i}^{\prime}}{b_{i}^{\prime}}$

where $d_{i}$ is the length of the contour line of a given cross section of the bark (cm); $b_{i}$ and $b_{i}^{\prime}$ are the lengths of the curvatures calculated according to the methods described above $(\mathrm{cm})$.

Assuming that a bark sample was divided into the representative number of strips following the adopted rules, according to the authors the average value of the coefficient of development of the contour line of the cross section $C_{s k}$ or $C_{s k}^{\prime}$ calculated for all cross sections sufficiently illustrates the differentiation of this feature for the entire surface of a given bark sample. Therefore, it is the coefficient of development of the interception surface $C_{\mathrm{sd}}$ or $C_{\mathrm{sd}}^{\prime}$ that was regarded as the measure that describes the degree of differentiation of the outer bark layer of trees; it is determined by means of formulas:

$C_{\mathrm{sd}}=\frac{\sum_{i=1}^{n} C_{s k i}}{n}$

or

$C_{\mathrm{sd}}^{\prime}=\frac{\sum_{i=1}^{n} C_{s k i}^{\prime}}{n}$

where $n$ is the number of cross sections of a given bark sample.

The values of the coefficients of development of the interception surface $C_{\mathrm{sd}}$ or $C_{\mathrm{sd}}^{\prime}$ obtained in this way were used to calculate the actual surface $A_{\mathrm{d}}$ and $A_{\mathrm{d}}^{\prime}$ of bark samples according to formulas 1 and 7 .

\section{Results and discussion}

Measurements covered the total of 77 bark samples obtained from the stems of 8 species of living coniferous and deciduous trees at the height of DBH. The researchers collected: 10 samples of the bark of Scots pine ( $P$. sylvestris), 11 samples of the bark of European larch $(L$. decidua), 10 samples of the bark of silver fir (Abies alba), 11 samples of the bark of Norway spruce (P. abies), 6 samples of the bark of sycamore maple (A. pseudoplatanus), 8 samples of the bark of silver birch (B. pendula), 10 samples of the bark of common oak ( $Q$. robur), and 10 samples of the bark of European beech ( $F$. sylvatica).

The lengths of the average curvatures $b_{\mathrm{a}}$ and $b_{\mathrm{a}}^{\prime}$ of particular bark samples, calculated using the methods described in the research methodology, differ from one another. Among the consequences of these differences are also differences in the values of the parameters calculated with their application, such as the model surface $A$ and $A^{\prime}$, the coefficient of development of the interception surface $C_{\mathrm{sd}}$ or $C_{\mathrm{sd}}^{\prime}$ and the actual surface $A_{\mathrm{d}}$ and $A_{\mathrm{d}}^{\prime}$. Examples of these differences for selected bark samples are shown in Table 1.

It should be noted that despite the differences in the surfaces $A$ and $A^{\prime}$, and in the coefficient of development of the interception surface $C_{\mathrm{sd}}$ or $C_{\mathrm{sd}}^{\prime}$, the actual surfaces of the samples $A_{\mathrm{d}}$ and $A_{\mathrm{d}}^{\prime}$ assume similar values. This is due to the fact that a shorter length or curvature $b_{\mathrm{a}}$ or $b_{\mathrm{a}}^{\prime}$ results in a higher value of the coefficient of development of the interception surface and vice versa: a higher length of the curvature results in a smaller value of the coefficient $C_{\mathrm{sd}}$ or $C_{\text {sd. }}^{\prime}$. Consequently, calculation of the actual surface $A_{\mathrm{d}}$ and $A_{\mathrm{d}}^{\prime}$ using formulas 1 and 7 results in only a small difference 
Table 1 Comparison of the parameters of selected bark samples defined by the length of curvatures $b_{\mathrm{a}}$ and $b_{\mathrm{a}}^{\prime}$ calculated with various methods

\begin{tabular}{|c|c|c|c|c|c|c|c|c|c|}
\hline Number of sample & $a$ & $b_{\mathrm{a}}$ & $b_{\mathrm{a}}^{\prime}$ & $C_{\mathrm{sd}}$ & $C_{\mathrm{sd}}^{\prime}$ & $A$ & $A^{\prime}$ & $A_{\mathrm{d}}$ & $A_{\mathrm{d}}^{\prime}$ \\
\hline Pine 3 & 8.87 & 8.02 & 7.46 & 1.53 & 1.65 & 71.14 & 66.17 & 108.84 & 109.18 \\
\hline Pine 6 & 11.99 & 9.43 & 8.73 & 2.27 & 2.44 & 113.07 & 104.67 & 256.66 & 255.40 \\
\hline Pine 7 & 15.31 & 8.94 & 9.05 & 2.21 & 2.18 & 136.87 & 138.56 & 302.49 & 302.05 \\
\hline Larch 3 & 9.50 & 8.79 & 8.82 & 1.88 & 1.87 & 83.51 & 83.79 & 156.99 & 156.69 \\
\hline Larch 6 & 9.81 & 9.30 & 9.02 & 2.05 & 2.17 & 91.23 & 88.49 & 187.03 & 192.02 \\
\hline Larch 8 & 10.76 & 7.89 & 7.67 & 2.22 & 2.28 & 84.90 & 82.53 & 188.47 & 188.17 \\
\hline Fir 4 & 9.35 & 7.52 & 7.43 & 1.01 & 1.01 & 70.31 & 69.47 & 71.02 & 70.17 \\
\hline Fir 8 & 13.46 & 6.25 & 6.28 & 1.29 & 1.29 & 84.13 & 84.53 & 108.52 & 109.04 \\
\hline Fir 10 & 14.51 & 9.33 & 9.41 & 1.45 & 1.43 & 135.38 & 136.54 & 196.30 & 195.25 \\
\hline Spruce 3 & 10.95 & 5,38 & 5.60 & 1.21 & 1.16 & 58.91 & 61.32 & 71.28 & 71.13 \\
\hline Spruce 4 & 8.62 & 6.63 & 6.95 & 1.49 & 1.42 & 57.15 & 59.91 & 85.15 & 85.07 \\
\hline Spruce 9 & 12.36 & 12.21 & 12.35 & 1.72 & 1.70 & 150.92 & 152.65 & 259.57 & 259.50 \\
\hline Birch 3 & 13.95 & 5.17 & 5.11 & 1.56 & 1.57 & 72.12 & 71.28 & 112.51 & 111.92 \\
\hline Birch 4 & 8.95 & 8.52 & 8.88 & 1.70 & 1.63 & 76.25 & 79.48 & 129.63 & 129.55 \\
\hline Birch 5 & 10.60 & 9.34 & 9.39 & 1.74 & 1.73 & 99.00 & 99.53 & 172.27 & 172.19 \\
\hline Oak 2 & 7.87 & 7.19 & 7.31 & 1.31 & 1.29 & 56.59 & 57.53 & 74.13 & 74.21 \\
\hline Oak 5 & 10.99 & 8.37 & 8.40 & 1.60 & 1.59 & 91.99 & 92.32 & 147.18 & 146.78 \\
\hline Oak 7 & 11.17 & 7.72 & 7.71 & 1.53 & 1.54 & 86.23 & 86.12 & 131.94 & 132.63 \\
\hline Beech 6 & 7.09 & 9.07 & 8.99 & 1.10 & 1.11 & 64.31 & 63.74 & 70.74 & 70.75 \\
\hline Beech 8 & 8.48 & 8.17 & 8.08 & 1.01 & 1.03 & 69.28 & 68.52 & 69.97 & 70.57 \\
\hline Beech 10 & 8.12 & 5.22 & 5.24 & 1.07 & 1.06 & 42.39 & 42.55 & 45.35 & 45.10 \\
\hline Maple 3 & 11.28 & 5.71 & 5.71 & 1.08 & 1.08 & 64.41 & 64.41 & 69.56 & 69.56 \\
\hline Maple 5 & 12.36 & 4.44 & 4.46 & 1.36 & 1.35 & 54.88 & 55.13 & 74.63 & 74.42 \\
\hline
\end{tabular}

where $a$ is the average length of the side of the sample parallel to the stem core $(\mathrm{cm}), b_{\mathrm{a}}$ is the average length of curvature of the sample calculated from the geometrical relations $(\mathrm{cm}), b_{\mathrm{a}}^{\prime}$ is the average length of curvature of the sample calculated in a subjective manner $(\mathrm{cm}), C_{\mathrm{sd}}$ and $C_{\mathrm{sd}}^{\prime}$ are the coefficients of development of the interception surface of bark calculated using formulas 10 and $11, A$ and $A^{\prime}$ are the model surfaces of bark samples calculated using formulas 2 and $6\left(\mathrm{~cm}^{2}\right), A_{\mathrm{d}}$ and $A_{\mathrm{d}}^{\prime}$ are the actual surfaces of bark samples calculated using formulas 1 and $7\left(\mathrm{~cm}^{2}\right)$

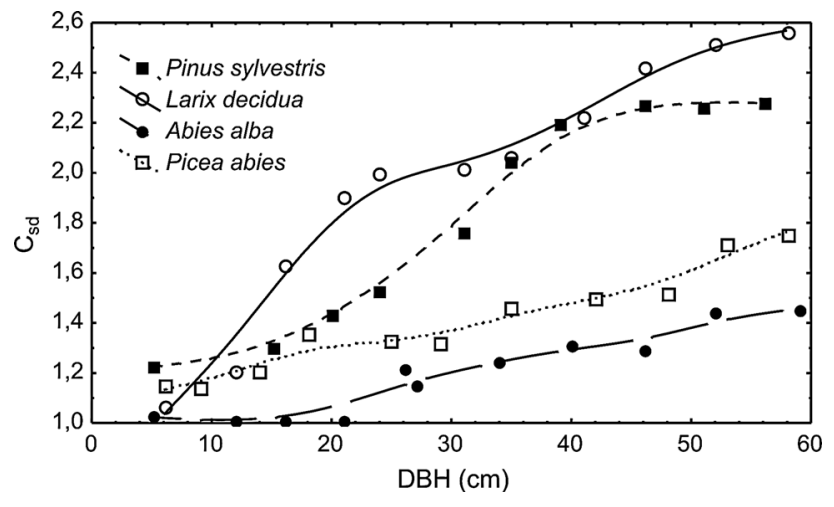

Fig. 3 A diagram showing the course of the coefficient of development of the interception surface of bark $C_{\mathrm{sd}}$, in relation to the diameter at breast height $(\mathrm{DBH})$ of trees of coniferous species

while it is the actual surface that constitutes the ultimate goal of the measurements (Table 1).

According to the authors, the method of calculating the length of curvature $b_{\mathrm{a}}$ using geometric patterns is methodically more correct than the second method in

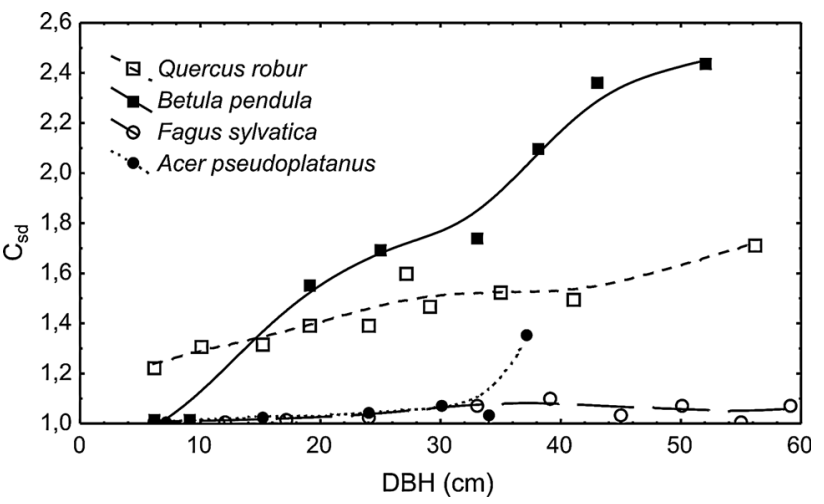

Fig. 4 A diagram showing the course of the coefficient of development of the interception surface of bark $C_{\mathrm{sd}}$, in relation to the diameter at breast height (DBH) of trees of deciduous species

which the measurements are performed in a subjective manner. Therefore, the study results were elaborated using the values obtained from the measurements of the average length of curvature $b_{\mathrm{a}}$ using the first method. The second method may find practical application in the calculation of 
the surface of the bark of trees with an irregular cross section, in which the diameters measured at breast height in two directions are substantially different from one another.

The results of the present study show differentiation the coefficient of development of the interception surface of bark $C_{\mathrm{sd}}$ at the level of DBH not only between particular species, but also its variation within a single species (Figs. 3, 4). A feature that is common for most species is a significant increase in the coefficient $C_{\mathrm{sd}}$ with the age (diameter at breast height) of trees, thereby increasing the interception surface of the bark of the tree stem $A_{\mathrm{d}}$. European beech $(F$. sylvatica) is an exception as its coefficient of development of the interception surface of bark $C_{\text {sd }}$ shows little variation in relation to the age of the trees.

Among all species, the largest values of the coefficient $C_{\text {sd }}$ characterize the bark of the thickest trees (Figs. 3, 4). Among the coniferous species, the highest values of the coefficient $C_{\mathrm{sd}}$ are reached by European larch $L$. decidua: $2.56(\mathrm{DBH}=58 \mathrm{~cm})$ and by Scots pine $P$. sylvestris: 2.28 $(\mathrm{DBH}=56 \mathrm{~cm})$, while among deciduous species-silver birch B. pendula: $2.44(\mathrm{DBH}=52 \mathrm{~cm})$. For coniferous species, the average values of the coefficient $C_{\mathrm{sd}}$ are reached by Norway spruce $P$. abies: $1.75(\mathrm{DBH}=58 \mathrm{~cm})$ while among deciduous species by common oak $Q$. robur: 1.72 $(\mathrm{DBH}=56 \mathrm{~cm})$. Relatively low values of the coefficient $C_{\mathrm{sd}}$ among coniferous species are reached by silver fir $A$. alba: $1.45(\mathrm{DBH}=59 \mathrm{~cm})$. The lowest values of the coefficient of development of the interception surface of bark $C_{\mathrm{sd}}$ are reached by European beech $F$. sylvatica: 1.07 $(\mathrm{DBH}=59 \mathrm{~cm})$. In the case of sycamore maple, the surface of bark in the younger age classes does not show large variation and its structure resembles the bark of European beech (Fig. 4). The coefficient of development of the interception surface of bark $C_{\mathrm{sd}}$ in young sycamore trees has values close to 1.00 , while in thicker trees it can be seen that the bark surface is highly differentiated, the bark is more protruding and very fragile. The authors managed to capture the moment when the coefficient of development of the interception surface of bark $C_{\mathrm{sd}}$ in sycamore maple begins to differentiate. This moment coincides with the period when the trees reach the diameter of about $37 \mathrm{~cm}$ at breast height. The present study does not include data on the formation of the coefficient of development of the interception surface of bark $C_{\mathrm{sd}}$ in sycamore maple trees which are more than $37 \mathrm{~cm}$ thick because of the difficulty in collecting samples of the bark with its structure left intact. However, based on field observations, it can be concluded that the coefficient $C_{\mathrm{sd}}$ for old sycamore maple trees certainly assumes high values, similar to larch and pine. Calculation of the surface of the bark for older sycamore trees requires the development of special methods for the sampling of the bark.

Within particular species, the highest variation of the coefficient of development of the interception surface of bark $C_{\mathrm{sd}}$ characterizes $B$. pendula, $L$. deciduas, and $P$. sylvestris, in which the coefficients of variation are, respectively, 31.31, 25.12, and $23.47 \%$ (Table 2). The smallest variation of the coefficient $C_{\mathrm{sd}}$ is shown by $F$. sylvatica $(3.41 \%)$.

Therefore, the species presented in the present study can be divided into three groups:

1. The group of species with the bark surface strongly growing with age of the trees. It includes: $P$. sylvestris, L. decidua, B. pendula, and A. pseudoplatanus.

2. The group of species with an average bark surface development with age. It includes: P. abies, $Q$. robur, and A. alba.

3. The group of species with the bark surface which develops only slightly with age. It includes $F$. sylvatica.

Analyzing the variability of the coefficient of development of the interception surface of bark $C_{\mathrm{sd}}$, with the age of

Table 2 Descriptive statistics of the coefficient of development of the interception surface of bark $C_{\text {sd }}$ for individual species

\begin{tabular}{|c|c|c|c|c|c|c|c|c|}
\hline Sspecies & $n$ & Mean & Median & Min & Max & SD & $\mathrm{CV}(\%)$ & $R^{2}$ \\
\hline P. sylvestris & 10 & 1.83 & 1.90 & 1.23 & 2.28 & 0.43 & 23.47 & 0.92 \\
\hline L. decidua & 11 & 1.96 & 2.02 & 1.07 & 2.56 & 0.49 & 25.12 & 0.91 \\
\hline P. abies & 11 & 1.41 & 1.36 & 1.14 & 1.75 & 0.21 & 14.78 & 0.94 \\
\hline A. alba & 11 & 1.20 & 1.22 & 1.01 & 1.45 & 0.17 & 14.05 & 0.90 \\
\hline Q. robur & 10 & 1.45 & 1.44 & 1.23 & 1.72 & 0.15 & 10.15 & 0.84 \\
\hline B. pendula & 8 & 1.74 & 1.72 & 1.02 & 2.44 & 0.55 & 31.31 & 0.96 \\
\hline A. pseudoplatanus $\mathrm{s}^{\mathrm{a}}$ & 6 & - & & - & - & - & - & - \\
\hline F. sylvatica & 10 & 1.05 & 1.03 & 1.01 & 1.10 & 0.04 & 3.41 & 0.30 \\
\hline
\end{tabular}

where $n$ is the sample size, $S D$ is the standard deviation, $C V$ is the coefficient of variation, $R^{2}$ is the coefficient of determination describing the dependence of the coefficient $C_{\mathrm{sd}}$ on the breast height diameter of trees

a Owing to the lack of data on the coefficient of development of the interception surface of bark $C_{\mathrm{sd}}$ for thick trees, the calculation of descriptive statistics was not performed 
Scots pine, European larch, and silver birch (Figs. 3, 4), it can be seen that there are two inflection points. The authors put forward the hypothesis that one of them may occur after the culmination of the growth of tree height, while the other occurs after the culmination of the growth of tree thickness. However, this hypothesis requires verification during further studies.

The present research results constitute a proposal of calculation of the bark surface of forest tree stems by means of the coefficient of development of the interception surface of bark $C_{\mathrm{sd}}$, describing the level of development of the outer surface layer of the bark. The values of the coefficients $C_{\mathrm{sd}}$ in the present study concern only the bark sections obtained at the breast height of trees and they cannot be used for the calculation of the actual surface of the bark of the whole stem. To determine actual surface of the bark of the whole stem, one should calculate the variability of the coefficient of development of the interception surface of bark $C_{\mathrm{sd}}$ for each species over the entire length of the tree stem, from its butt end to its top. These measurements may show large variations in the development of the coefficient $C_{\mathrm{sd}}$ within a single tree stem, and thus variation in the water capacity of the bark along the stem. This seems to be reasonable due to the variability of the coefficient $C_{\mathrm{sd}}$ with the age of trees within a single species (Figs. 3, 4). Similarly to the age of the trees, the coefficient $C_{\text {sd }}$ should vary along the tree stems.

Obtaining the average values of coefficients $C_{\text {sd }}$ depending on the age and species of trees will be of great cognitive and practical importance in the modeling of water processes occurring in forest ecosystems. Based on the average DBH and height of a stand, as well as the average values of the coefficients $C_{\mathrm{sd}}$ for the trees of particular species, it will be easy to determine the entire interception surface of the stem for whole stands. The application of this methodology for the calculation of the actual surface of twigs and branches along with the knowledge of the surface of the assimilation apparatus will allow for determination of the actual interception surface of stands.

\section{Conclusions}

The coefficient of development of the interception surface of bark $C_{\mathrm{sd}}$ allows for objective assessment of the degree of bark surface differentiation between different species.

The coefficient $C_{\mathrm{sd}}$, is a measure to differentiate bark morphology and indicates that each species has its own properties in the shaping of the surface whose development is dynamic and progresses with the age of trees.

Owing to the mathematical form of recording the degree of differentiation of the bark surface, the coefficient $C_{\mathrm{sd}}$ may be useful for modelling the hydrological processes occurring in forest ecosystems. As a measure of surface differentiation, it allows for obtaining certain calculation results when analysing water properties of the bark, thanks to which one can better interpret the interception processes of the bark of various species.

Acknowledgments We thank the two anonymous reviewers for their valuable comments and suggestions on the manuscript.

Conflict of interest These investigations were supported by a grant for young scientists from Polish Ministry of Science and Higher Education (No. BM/4419/KIL/12, Determination of the water storage capacity of bark of forest tree under laboratory conditions).

Open Access This article is distributed under the terms of the Creative Commons Attribution License which permits any use, distribution, and reproduction in any medium, provided the original author(s) and the source are credited.

\section{References}

Aboal JR, Morales D, Hernández M, Jiménez MS (1999) The measurement and modelling of the variation of stemflow in a laurel forest in Tenerife Canary Islands. J Hydrol 221(3):161-175

Adams DC, Jackson JF (1995) Estimating the allometry of tree bark. Am Midl Nat 134:99-106

Barlow J, Lagan BO, Reres CA (2003) Morphological correlates of fire-induced tree mortality in a central Amazonian forest. J Trop Ecol 19:291-299

Bates JW, Brown DH (1981) Epiphyte differentiation between Quercus petraea and Fraxinus excelsior trees in a maritime area of South West England. Vegetatio 48(1):61-70

Bauer G, Speck T, Blömer J, Bertling J, Speck O (2010) Insulation capability of the bark of trees with different fire adaptation. J Mater Sci 45:5950-5959

Calder IR (1996) Dependence of rainfall interception on drop size: 1. development of the two-layer stochastic model. J Hydrol $185: 363-378$

Calder IR (1999) Dependence of rainfall interception on drop size-a replay to the comment by Uijlenhoet and Sticker. J Hydrol 217:164-165

Cebulska M, Osuch B (1998) Określenie zdolności intercepcyjnej mchu na przykładzie płonnika strojnego Polytrichum attenuatum Menz. Las i Woda Mater Pokonf Międzyn Konf Nauk Wyd PK Kraków: 271-279

Eremin VM (1977) Characteristics of anatomic structure of bark from various forms of Picea excelsa LINK. Izv Vyssh Uchebn Zaved Lesn Zh

Etverk I (1972) Scaly-barked and smooth-barked spruce. Loodusuur Seltsi Aastaraam 61:116-130

Everhart SE, Ely JS, Keller HW (2009) Evaluation of tree canopy epiphytes and bark characteristics associated with the presence of corticolous myxomycetes. Botany 87:509-517

Grochowski W (1990) Uboczna produkcja leśna. PWN Warszawa

Harmon ME (1984) Survival of trees after low-intensity surface fires in Great Smoky Mountains National Park. Ecology 65:796-802

Hengst GE, Dawson JO (1994) Bark properties and fire resistance of selected tree species from the central hardwood region of North America. Can J For Res 24(4):688-696

Herwitz SR (1985) Interception storage capacities of tropical rainforest canopy trees. J Hydrol 77:237-252 
Hoffmann J (1958) Untersuchungen über die Rindenstärke der Fichte auf verschiedenen Standorten im südöstlichen Thüringer Wald. Wiss Z TU, Dresden 7: 361-368

Jackson JA (1979) Tree surfaces as foraging substrates for insectivorous birds. In: Dickson JC, Connor RN, Fleet JA, Jackson JA, Kroll JC (eds) The role of insectivorous birds in forest ecosystems. Academic Press, New York, pp 69-93

Keim RF, Skaugset AE, Weiler M (2006) Storage of water on vegetation under simulated rainfall of varying intensity. Adv Water Resour 29:974-986

Klaassen W, Bosveld F, de Walter E (1998) Water storage and evaporation as constituents of rainfall interception. J Hydrol 212(213):36-50

Kuusinen M (1996) Epiphyte flora and diversity on basal trunks of six old-growth forest tree species in southern and middle boreal Finland. Lichenologist 28(5):443-463

Levia DF, Herwitz SR (2005) Interspecific variation of bark water storage capacity of three deciduous tree species in relation to stemflow yield solute flux to forest soils. Catena 64:117-137

Levia DF, Wubbena NP (2006) Vertical variation of bark water storage capacity of Pinus strobus L. (Eastern White Pine) in Southern Illionois. Northeast Nat 13(1):131-137

Levia DF, Van Stan II JT, Mage SM, Kelley-Hauske PW (2010) Temporal variability of stemflow volume in a beech-yellow poplar forest in relation to tree species and size. J Hydrol 380(1):112-120

MacFarlane DW, Luo A (2009) Quantifying tree and forest bark structure with a bark-fissure index. Can $J$ For Res 39(10):1859-1870

Návar J (1993) The causes of stemflow variation in three semi-arid growing species of northeastern Mexico. J Hydrol 145(1): $175-190$

Osuch B (1998) Powierzchnia drzew jako podstawa zbiornika intercepcyjnego drzewostanu. Las i Woda Mater Pokonf Międzyn Konf Nauk Wyd PK Kraków 322-334

Osuch B, Homa A, Feliks M (2005) Opis pojemności zbiornika intercepcyjnego sosny zwyczajnej (Pinus sylvestris) - So. Czasopismo Tech 10-Ś Wyd PK Kraków 87-101

Osuch B, Homa A, Feliks M, Kulig M (2005a) Zbiornik intercepcyjny brzozy brodawkowatej (Betula pendula Roth). Czasopismo Tech 10- Ś Wyd PK Kraków 103-118
Öztürk Ş, Güvenç Ş (2010) Comparison of the epiphytic lichen communities growing on various tree species on Mt. Uludağ (Bursa, Turkey). Turk J Bot 34:449-456

Öztürk Ş, Oran S (2011) Investigations on the bark pH and epiphytic lichen diversity of Quercus taxa found in Marmara region. J Appl Biol Sci 5:27-33

Pawłowski B (1956) Flora Tatr: rośliny naczyniowe (vol. 1). PWN Warszawa

Pinard MA, Huffman J (1997) Fire resistance and bark properties of trees in a seasonally dry forest in eastern Bolivia. J Trop Ecol 13(5):727-740

Pypker TG, Levia DF, Staelens J, Van Stan II JT (2011) Canopy structure in relation hydrological and biogeochemical fluxes. For Hydrol Biogeochem Ecol Stud 216(4):371-388

Schulz H, Popp P, Huhn G, Stärk HJ, Schüürmann G (1999) Biomonitoring of airborne inorganic and organic pollutants by means of pine tree barks. I. Temporal and spatial variations. Sci Total Environ 232(1):49-58

Stephenson SL (1989) Distribution and ecology of myxomycetes in temperate forests. II. Patterns of occurrence on bark surface of living trees, leaf litter, and dung. Mycologia 81:60-621

Suliński J, Starzak R, Kucza J (2001) Weryfikacja wzoru wyrażającego intercepcję drzew w zależności od natężenia i czasu trwania opadu deszczu w warunkach eksperymentalnych. Acta Agr Silv Ser Silv 39:3-16

Valovà M, Bieleszovà S (2008) Interspecific variations of bark's water storage capacity of chosen types of trees and the dependence on occurance of epiphytic mosses. Geosci Eng LIV 4:45-51

Van Stan JT, Levia DF (2010) Inter- and intraspecific variation of stemflow production from Fagus grandifolia Ehrh. (American beech) and Liriodendron tulipifera L. (yellow poplar) in relation to bark microrelief in the eastern United States. Ecohydrology 3(1):11-19

Van Stan JT, Jarvis MT, Levia DF (2010) An automated instrument for the measurement of bark microrelief. Instrum Meas IEEE Trans 59(2):491-493

West P (2009) Tree and forest measurements. Springer, Germany 